\title{
Phytate Degradation by Fungi and Bacteria that Inhabit Sawdust and Coffee Residue Composts
}

\author{
Mohamed Fathallh EIDA ${ }^{1,2}$, TOShinORi NAGAOKA ${ }^{1 *}$, Jun WASAKI $^{1}$, and KenJI KounO ${ }^{1}$ \\ ${ }^{1}$ Graduate School of Biosphere Science, Hiroshima University, 1-4-4, Kagamiyama, Higashi-hiroshima, Hiroshima \\ 739-8528, Japan and; ' Agricultural Microbiology Department, National Research Center, 33 El Behous St., Dokki, \\ 12622 Cairo, Egypt
}

(Received April 11, 2012—Accepted August 22, 2012—Published online October 26, 2012)

Phytate is the primary source of organic phosphorus, but it cannot be directly utilized by plants and is strongly adsorbed by the soil, reducing bioavailability. Composting is a process used to improve the bioavailability of phytate in organic wastes through degradation by microorganisms. In this study, we aimed to investigate the phytate-degrading ability of fungi and bacteria that inhabit sawdust compost and coffee residue compost, and their contribution to the composting process. In the plate assay, the fungi that formed clear zones around their colonies belonged to the genera Mucor, Penicillium, Galactomyces, Coniochaeta, Aspergillus, and Fusarium, while the bacteria belonged to the genera Pseudomonas, Enterobacter, Chitinophaga, and Rahnella. Eight fungal isolates (genera Mucor, Penicillium, Galactomyces, and Coniochaeta) and four bacterial isolates (genera Pseudomonas, Enterobacter, and Rahnella) were selected to evaluate phytase activity in their liquid culture and their ability to degrade phytate in organic materials composed of mushroom media residue and rice bran. The selected fungi degraded phytate in organic materials to varying degrees. Penicillium isolates showed the highest degradation ability and Coniochaeta isolate exhibited relatively high degradation ability. The clear zone diameters of these fungal isolates displayed significantly positive and negative correlations with inorganic and phytate phosphorus contents in the organic materials after incubation, respectively; however, none of the selected bacteria reduced phytate phosphorus in organic materials. It is therefore possible that fungi are major contributors to phytate degradation during composting.

Key words: phytate, degradation, bacteria, fungi, compost

Composting is the process used to transform organic wastes accumulated from human activity and other waste biomass into substances that may be used for fertilizing the soil and improving the growth of cultivated plants (33). The degradation processes during composting are mainly catalyzed by the action of microorganisms (58). To assess the composting process, it is important to study and understand the roles of microbial communities in the degradation processes. As a result, studies have been performed to evaluate the cellulolytic and hemicellulolytic activities of fungi and cellulose-decomposing bacteria isolated from coffee residue compost (CRC) and sawdust compost (SDC) by using azurine cross-linked substrates for cellulase, xylanase, $\beta$-glucanase, and mannanase $(12,13)$.

Phosphorus $(\mathrm{P})$ is the most essential nutritional element for sustaining all life, and hence food production, on our planet $(2,24)$. This element is also a component of key molecules such as nucleic acids, phospholipids, and ATP. Consequently, plants cannot grow without a reliable supply of $\mathrm{P}$ (53). Over the last century, $\mathrm{P}$ resources have been intensively depleted by human activities. On the basis of the current rate of depletion, phosphate reservoirs will not last more than 100 years (56). This scarcity of $\mathrm{P}$ resources demands effective usage of all allowed $P$ sources, including inorganic and organic $\mathrm{P}$ accumulated in waste materials and soil for sustainable agriculture. Compost amendment also

\footnotetext{
* Corresponding author. E-mail: tnagaok@hiroshima-u.ac.jp; Tel: +81-82-424-7969; Fax: +81-82-424-0791.
}

enhances biological properties such as phosphate-solubilizing bacteria, microbial biomass $\mathrm{P}$, and improved $\mathrm{P}$ availability and utilization by plants in andosols and granitic regosols $(62,63)$.

Phytate (myo-inositol hexakisphosphate) exists in a wide diversity of environments, including arable, forest, and grassland soils, as well as aquatic environments. In the terrestrial ecosystem, phytate is generated by plants (59). In most plants, a large portion of $\mathrm{P}$ exists in the form of phytate as a complex salt of calcium or magnesium, mainly in seeds. Phytate P constitutes the major portion $(60-82 \%)$ of total $\mathrm{P}$ in cereal grains, oilseeds, and grain legumes, with $1-25 \%$ of total $\mathrm{P}$ being found in various roots and tubers and small amounts in leaves and $56-77 \%$ of total $\mathrm{P}$ in rice bran and various oilseed meals (48). Plants and non-ruminant animals poorly utilize these phytates by direct means (19). For instance, phytate in the soil cannot be utilized directly by plants until it has been hydrolyzed to release phosphate (40). Improving the bioavailability of phytate $\mathrm{P}$ to plants might be beneficial for reducing the amount of $\mathrm{P}$ fertilization in agricultural environments (30). Phytate has the ability to bind strongly to mineral surfaces, especially clays (7), and forms insoluble metal complexes $(8,21)$. These properties may render phytate resistant to mineralization by microbial attack (59), resulting in its accumulation in soils.

The degradation of phytate is catalyzed by enzymes called phytases ( $m y o$-inositol hexakisphosphate phosphohydrolases; EC 3.1.3.8, 3.1.3.26, and 3.1.3.72), which are produced by various organisms, such as plants, animals, and micro- 
organisms (35). A large number of microorganisms, including bacteria, yeasts, and filamentous fungi, have been identified as phytase producers $(29,31,44,49,61)$. Phytate-hydrolyzing microorganisms inhabit wide and diverse environments, indicating that the biodegradation of phytate might be accomplished in a variety of ecosystems (23). It has been shown that phytate-utilizing bacteria may improve the acquisition of $\mathrm{P}$ by plants (50); however, few studies have focused on the degradation of phytate in organic wastes (16). Composting is an important process that may improve the bioavailability of $\mathrm{P}$ through the degradation of organic $\mathrm{P}$ by microorganisms (15); therefore, the evaluation of microorganisms that inhabit composts and their phytate degradation ability might contribute towards improving the quality of composts.

In the current study, we aimed to investigate the phytatedegrading ability of fungi and bacteria isolated from SDC and CRC. Fungal and bacterial isolates were screened to select effective isolates by the plate assay using phytase screening medium (PSM) containing calcium phytate because phyate mainly exists as insoluble salts bound with metals such as calcium and magnesium in organic materials. The phytase activity in liquid culture and the degradation ability of phytate in organic material composed of mushroom media residue and rice bran were evaluated using the selected isolates.

\section{Materials and Methods}

\section{Compost samples}

SDC produced from the residue of culture media for mushrooms was obtained from the Agricultural Cooperative Association of Saitama Prefecture, while CRC was collected from a composting center located in Hiroshima Prefecture. In brief, these materials were produced by composting heaps that were turned periodically for 2-3 months until they reached maturity. Compost samples $(0.4$ g) were digested with a 1:1 mixture of concentrated $\mathrm{H}_{2} \mathrm{SO}_{4}$ and concentrated $\mathrm{HNO}_{3}(10 \mathrm{~mL})$ in a Kjeldahl flask for total $\mathrm{P}$ analysis. $\mathrm{P}$ content was determined spectrophotometrically (UV mini 1240; Shimadzu, Kyoto, Japan) using the ammonium molybdate-ascorbic acid method (43). Total $\mathrm{C}$ and total $\mathrm{N}$ contents of the composts were determined using a combustion method with a $\mathrm{CN}$ analyzer (MT-700; Yanaco Kyoto, Japan). The chemical properties of SDC and CRC are presented in Table 1.

\section{Fungal and bacterial isolates}

The fungal isolates used in this study were obtained from SDC and CRC to evaluate their cellulolytic and hemicellulolytic activities (12). In total, 47 isolates were used, incuding nine Mucor, seven Penicillium, three Galactomyces, 11 Coniochaeta, 14 Trichodermal Hypocrea, two Aspergillus, and one Fusarium. The 21 cellulolytic bacterial isolates examined in this study, which were obtained from SDC and CRC (13), were four Streptomyces, 13 Microbispora, two Paenibacillus, and two Cohnella.
The bacteria that formed clear zones around their colonies were isolated from the same SDC and CRC using the dilution plate method. The primary suspensions were prepared by suspending an equivalent of $10 \mathrm{~g}$ oven-dry weight of each compost type in $90 \mathrm{~mL}$ sterilized distilled water and shaking $(150 \mathrm{rpm})$ for $30 \mathrm{~min}$ at room temperature. Then, 10-fold serial dilutions were prepared in sterile distilled water. One hundred microliters from the $10^{-4}$ dilution of each compost type was spread on phytase screening medium (PSM), according to the method used by Yoon et al. (65). PSM agar is composed of calcium phytate, $5.0 \mathrm{~g} \mathrm{~L}^{-1} ;\left(\mathrm{NH}_{4}\right)_{2} \mathrm{SO}_{4}, 3.0 \mathrm{~g} \mathrm{~L}^{-1} ; \mathrm{CaCl}_{2}$, $0.1 \mathrm{~g} \mathrm{~L}^{-1} ; \mathrm{MnSO}_{4} \cdot 5 \mathrm{H}_{2} \mathrm{O}, 0.1 \mathrm{~g} \mathrm{~L}^{-1} ; \mathrm{FeSO}_{4} \cdot 7 \mathrm{H}_{2} \mathrm{O}, 0.1 \mathrm{~g} \mathrm{~L}^{-1}$; and glucose, $10 \mathrm{~g} \mathrm{~L}^{-1}$. The $\mathrm{pH}$ was adjusted to 7.0. The plates were incubated at $35^{\circ} \mathrm{C}$ for $7 \mathrm{~d}$ because of the better formation of clear zones at $35^{\circ} \mathrm{C}$ than $30^{\circ} \mathrm{C}$. Five plates were prepared for each compost type. The colonies surrounded by large clear zones were selected from the most typical plate and transferred to trypto-soya agar (TSA; Nissui Pharmaceutical, Tokyo, Japan) plates. A single colony of each isolate was frequently transferred on TSA to obtain pure cultures. Four bacteria were isolated from the SDC and two were isolated from the CRC.

\section{DNA extraction and polymerase chain reaction amplification}

DNA extraction and polymerase chain reaction (PCR) amplification from the bacterial isolates were performed according to the methods used in a previous study (13). In brief, genomic DNA was extracted using the boiling method. DNA solution was used as a template for PCR amplification. PCR was performed with universal bacterial primers for the $16 \mathrm{~S}$ rRNA gene; $27 \mathrm{~F}$ and 1492R were used as the forward and reverse primers, respectively (37). PCR amplifications were conducted using the GeneAmp PCR system 2700 by following the conditions described in a previous study (13). PCR products were analyzed by agarose gel electrophoresis and then purified using the QIAquick PCR purification kit (Qiagen, Hilden, Germany), according to the manufacturer's instructions.

\section{Sequencing and data analysis}

The 16S rRNA gene sequences of the isolated bacteria were determined by direct sequencing of the purified PCR-amplified 16S rDNA fragments. The amplified 16S rRNA fragments were sequenced using the BigDye Terminator v3.1 Cycle Sequencing Kit (Applied Biosystems, Foster City, CA, USA) on an Applied Biosystems 3730xl DNA analyzer. An almost complete 16S rRNA gene was sequenced from each isolate using the following oligonucleotides: 27F, 515F (60), F984 (22), and 519R (37). The $16 \mathrm{~S}$ rDNA sequences of the isolated bacteria were compared with those of closely related species deposited in the GenBank database (http://blast.ncbi.nlm.nih.gov/Blast.cgi) using the nucleotide-nucleotide basic local alignment search tool (BLASTn). A phylogenetic tree based on 16S rRNA gene partial sequences was constructed using the neighbor-joining method on the MEGA5 program (55).

\section{Screening of fungal and bacterial isolates by the plate assay}

Fungal isolates were grown on potato dextrose agar (PDA; Nissui Pharmaceutical, Tokyo, Japan) and then agar plugs $(6 \mathrm{~mm}$ in diameter), with mycelium excised from the plate of each isolate. The agar plugs were placed in the center of a PSM agar plate surface in three replicates and incubated at $25^{\circ} \mathrm{C}$ for $7 \mathrm{~d}$. In the case of

Table 1. Chemical properties of SDC and CRC

\begin{tabular}{cccccc}
\hline \multirow{2}{*}{ Compost used $^{\mathrm{a}}$} & Dry matter $\left(\mathrm{g} \mathrm{kg}^{-1}\right)$ & $\mathrm{C}$ & $\mathrm{N}$ & $\mathrm{P}$ & \multirow{2}{*}{$\mathrm{C} / \mathrm{N} \mathrm{ratio}$} \\
\cline { 3 - 5 } & 538 & & $\left(\mathrm{~g} \mathrm{~kg}^{-1}\right)^{\mathrm{b}}$ & 12.3 & 30.0 \\
SDC & 390 & 456 & 14.7 & 0.7 & 20.9 \\
\hline CRC & 448 & 21.4 & \\
\hline
\end{tabular}

\footnotetext{
${ }^{a}$ SDC, sawdust compost; CRC, coffee residue compost.
}

${ }^{\mathrm{b}}$ Values are expressed on an oven-dry basis. 
bacteria, bacterial cells grown on TSA were inoculated at a point on the PSM agar plate surface and incubated for $7 \mathrm{~d}$ at $35^{\circ} \mathrm{C}$. After incubation, the diameter of the clear zone and diameter of fungal and bacterial growth were measured. Three replicates of each experiment were conducted. Screening was carried out comparing the clear zone diameter and the ratio of clear zone diameter to growth diameter (CD/GD ratio), since the growth of microbes greatly affects the size of the clear zone.

\section{Measurement of phytase activity}

The selected eight fungal isolates (SDCF1, SDCF3, SDCF5, SDCF11, SDCF17, SDCF18, SDCF22, and CRCF1) and four bacterial isolates (PSDCB1, PSDCB3, PCRCB18, and PCRCB19) were inoculated at a rate of $10^{5}$ and $10^{6} \mathrm{cfu} \mathrm{mL}^{-1}$, respectively, into $30 \mathrm{~mL}$ PSM broth (65) with modification, using sodium phytate instead of calcium phytate at the same rate $\left(5.0 \mathrm{~g} \mathrm{~L}^{-1}\right)$ in $100 \mathrm{~mL}$ Erlenmeyer flasks. Sodium phytate was added separately to autoclaved media containing other constituents after $\mathrm{pH}$ adjustment and filtration with a sterile membrane filter (DISMIC 25CS020AS, $0.2 \mu \mathrm{m}$; Toyo Roshi, Tokyo, Japan). The pH of PSM broth was adjusted to 5.5 for fungi and to 7.0 for bacteria. The media was incubated with orbital shaking $(120 \mathrm{rpm})$ at $30^{\circ} \mathrm{C}$ for $5 \mathrm{~d}$. All treatments were conducted in triplicate. After incubation, the liquid cultures were centrifuged at 3,000 rpm for $15 \mathrm{~min}$ and then filtered through a sterile membrane filter (DISMIC 25CS020AS, $0.2 \mu \mathrm{m}$ ). Phytase activity of the culture filtrates was measured according to the method described by George et al. (18) in larger volume. Briefly, the reaction solution composed of $3 \mathrm{~mL}$ of $25 \mathrm{mM}$ MES buffer ( $\mathrm{pH}$ 5.5), $1 \mathrm{~mL}$ of $10 \mathrm{mM}$ sodium phytate ( $\mathrm{pH}$ adjusted to 5.5) as the substrate and $1 \mathrm{~mL}$ culture filtrate was incubated at $37^{\circ} \mathrm{C}$ for $1 \mathrm{~h}$. The reaction was stopped by adding $5 \mathrm{~mL}$ of $10 \%$ trichloroacetic acid. The liberated inorganic $\mathrm{P}$ in the solution was determined colorimetrically using a malachite green reagent (26), and phytase activity was expressed as $\mu \mathrm{mol}$ inorganic $P$ released per $1 \mathrm{~mL}$ culture filtrate within a minute. Inorganic $\mathrm{P}$ in the culture filtrate was also determined using the malachite green reagent.

\section{Incubation of organic materials inoculated with the selected bacteria and fungi}

Organic materials inoculated with selected microorganisms were cultured in a semisolid state, according to the method published by Lopez et al. (38), to investigate their ability to degrade phytate in organic materials. A mixture of $3.49 \mathrm{~g}(2.0 \mathrm{~g}$ in dry weight $)$ mushroom media residue, which was mainly composed of sawdust and $0.53 \mathrm{~g}(0.5 \mathrm{~g}$ in dry weight $)$ rice bran, was placed in a $100 \mathrm{~mL}$ Erlenmeyer flask and $18 \mathrm{~mL}$ distilled water was added. The mixture of organic materials was inoculated with $0.5 \mathrm{~mL}$ fungal or bacterial suspensions $\left(10^{6} \mathrm{cfu} \mathrm{g}^{-1}\right.$ dry matter) after autoclaving at $121^{\circ} \mathrm{C}$ for $20 \mathrm{~min}$ and incubated with rotary shaking $(120 \mathrm{rpm})$ at $30^{\circ} \mathrm{C}$ for 7 and $14 \mathrm{~d}$ in darkness. After incubation, the culture was autoclaved at $121^{\circ} \mathrm{C}$ for $20 \mathrm{~min}$, dried at $80^{\circ} \mathrm{C}$ for $12 \mathrm{~h}$, and weighed. Three replicates of all treatments were performed. The chemical properties of mushroom media residue and rice bran are presented in Table 2. The $\mathrm{pH}$ of the mixture of mushroom media residue and rice bran was $6.0\left(1: 10, \mathrm{H}_{2} \mathrm{O}\right)$.

\section{Determination of phytate and inorganic $P$}

Phytate $\mathrm{P}$ was measured according to the method used by Raboy et al. (47), with some modifications. Briefly, $30 \mathrm{~mL}$ of $0.4 \mathrm{M} \mathrm{HCl}: 0.7$ $\mathrm{M} \mathrm{Na}_{2} \mathrm{SO}_{4}$ was added to each $100 \mathrm{~mL}$ Erlenmeyer flask containing whole dried organic materials and extracted by shaking $(120 \mathrm{rpm})$ at room temperature for $12 \mathrm{~h}$ after sealing. Three replicates of all treatments were performed. The suspension was centrifuged at 3000 $\mathrm{rpm}$ for $15 \mathrm{~min}$ and filtered. Ten milliliters of distilled water and 5 $\mathrm{mL}$ of $15 \mathrm{mM} \mathrm{FeCl}_{3}: 0.2 \mathrm{M} \mathrm{HCl}$ were added to $10 \mathrm{~mL}$ filtrate in a $50 \mathrm{~mL}$ glass centrifuge tube. The mixture was heated in a boiling water bath for $30 \mathrm{~min}$, allowed to cool down, and centrifuged at $3000 \mathrm{rpm}$ for $15 \mathrm{~min}$, followed by washing twice with $0.2 \mathrm{M} \mathrm{HCl}$ to obtain the ferric phytate precipitate. The precipitated ferric phytate was digested with $10 \mathrm{~mL} \mathrm{H}_{2} \mathrm{SO}_{4}: \mathrm{HNO}_{3}(1: 1, \mathrm{v} / \mathrm{v})$. Phytate $\mathrm{P}$ in the diluted solution after digestion and inorganic $\mathrm{P}$ (orthophosphate $\mathrm{P}$ ) in the filtrate after extraction with $0.4 \mathrm{M} \mathrm{HCl}: 0.7 \mathrm{M} \mathrm{Na}_{2} \mathrm{SO}_{4}$ were determined colorimetrically (43).

\section{Statistical analysis}

Statistical analyses were performed using JMP 8 (SAS Institute). Pair-wise correlations were calculated between clear zone diameters and the $\mathrm{CD} / \mathrm{GD}$ ratio in the plate assay that contained fungal isolates and phytate $\mathrm{P}$ and inorganic $\mathrm{P}$ contents in organic materials inoculated with fungal isolates after incubation.

\section{Accession numbers of nucleotide sequences}

Nucleotide sequences of the partial 16S rRNA genes of the bacterial isolates were deposited in GenBank under accession numbers JQ864387-JQ864392.

\section{Results}

\section{Isolation and phylogenetic analysis of bacterial isolates}

Four isolates (PSDCB1, PSDCB3, PSDCB5, and PSDCB6) were isolated from SDC and two isolates (PCRCB18 and PCRCB19) from CRC, and they were subjected to phylogenetic analysis and a phytate degradation study. The results of the BLASTn search (Table 3) and the constructed phylogenetic tree (Fig. 1) based on the sequences of $16 \mathrm{~S}$ rRNA genes revealed that the isolated bacteria belonged to four genera (Pseudomonas, Enterobacter, Chitinophaga, and Rahnella). Genera Pseudomonas, Enterobacter, and Chitinophaga were isolated from SDC, while the Rahnella genus was isolated from CRC. The isolate PSDCB1 was closest to $P$. extremaustralis CT14- $3^{\mathrm{T}}$ in the phylogenetic tree, with $100 \%$ similarity. The sequences of PSDCB3 and PSDCB5 were matched with $E$. nimipressuralis LMG $10245^{\mathrm{T}}$ and E. amnigenus $\mathrm{JCM} 1237^{\mathrm{T}}$, with 99.3 and $99.9 \%$ similarity, respectively. The identity of isolate PSDCB6 with the closest type strain $C$. arvensicola DSM $3695^{\mathrm{T}}$ was $99.6 \%$. Both bacteria isolated from CRC belonged to the Rahnella genus, as revealed by the phylogenetic tree

Table 2. Chemical properties of organic materials

\begin{tabular}{|c|c|c|c|c|c|c|c|c|}
\hline \multirow{2}{*}{ Organic material } & \multirow{2}{*}{$\begin{array}{l}\text { Dry matter } \\
\left(\mathrm{g} \mathrm{kg}^{-1}\right)\end{array}$} & $\mathrm{C}$ & $\mathrm{N}$ & $\mathrm{P}$ & Phy-Pa & $\mathrm{IP}^{\mathrm{b}}$ & \multirow{2}{*}{$\mathrm{C} / \mathrm{N}$ ratio } & \multirow{2}{*}{$\begin{array}{c}\mathrm{pH} \\
\left(1: 10, \mathrm{H}_{2} \mathrm{O}\right)\end{array}$} \\
\hline & & & $\mathrm{g} \mathrm{kg}^{-1}$ & & \multicolumn{2}{|c|}{$\left(\mathrm{g} \mathrm{kg}^{-1}\right)^{\mathrm{c}}$} & & \\
\hline Mushroom media residue & 573 & 447 & 11.2 & 2.2 & $\mathrm{ND}^{\mathrm{d}}$ & 1.3 & 39.9 & 5.6 \\
\hline Rice bran & 935 & 457 & 22.2 & 19.1 & 16.9 & 2.0 & 20.6 & 6.9 \\
\hline
\end{tabular}

\footnotetext{
a Phy-P, Phytate P.

${ }^{\mathrm{b}} \mathrm{IP}$, Inorganic P (extracted with $0.4 \mathrm{M} \mathrm{HCl}: 0.7 \mathrm{M} \mathrm{Na}_{2} \mathrm{SO}_{4}$ ).

${ }^{c}$ Values are expressed on an oven-dry basis.

${ }^{\mathrm{d}} \mathrm{ND}$, not detectable.
} 
Table 3. Closest relatives of bacterial isolates from SDC and CRC in the BLASTn results for 16S rRNA gene sequences

\begin{tabular}{|c|c|c|c|c|}
\hline Isolate No. & Accession No. & Closest relative (Accession No.) ${ }^{\mathrm{a}}$ & Length & Identity (\%) \\
\hline PSDCB1 & JQ864387 & Pseudomonas extremaustralis (AJ583501) & 1459 & $1459 / 1459(100)$ \\
\hline PSDCB3 & JQ864388 & Enterobacter sp. (DQ279307) & 1462 & $1455 / 1457(99.9)$ \\
\hline PSDCB5 & JQ864389 & Enterobacter sp. (JF939050) & 1462 & $1461 / 1462(99.9)$ \\
\hline PSDCB6 & JQ864390 & Chitinophaga arvensicola (AB681051) & 1449 & $1444 / 1450(99.6)$ \\
\hline PCRCB18 & JQ864391 & Rahnella aquatilis (CP003244) & 1465 & $1463 / 1465(99.9)$ \\
\hline PCRCB19 & JQ864392 & Rahnella sp. (AM167519) & 1465 & $1464 / 1465$ (99.9) \\
\hline
\end{tabular}

${ }^{a}$ Closest relative was chosen from highly ranked representative isolates in the BLASTn results.

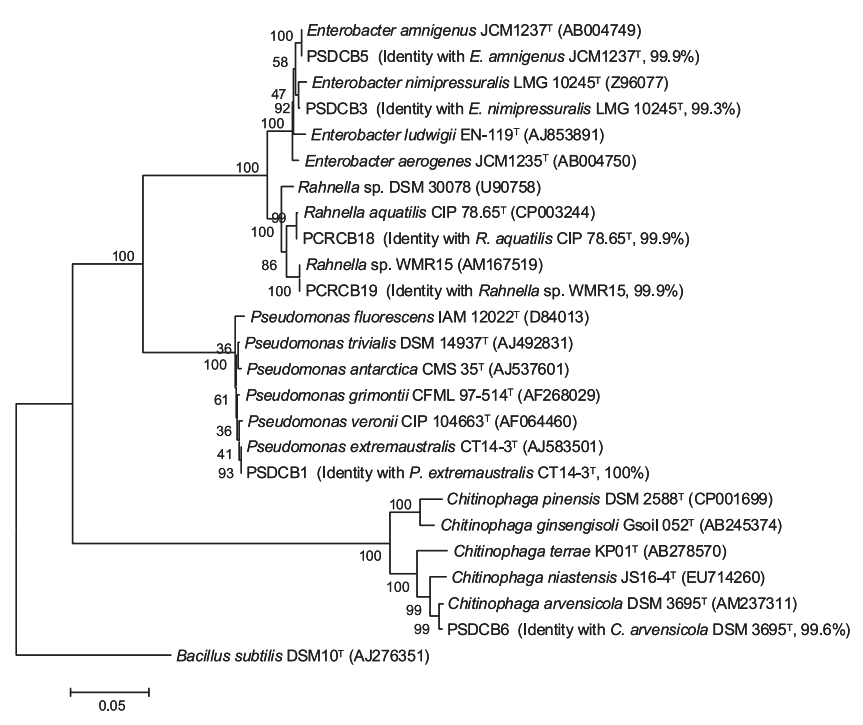

Fig. 1. Phylogenetic tree based on the relationship among the $16 \mathrm{~S}$ rRNA sequences of phytate-degrading bacteria isolated from SDC and CRC and type strains of close species. Rahnella sp. WMR15 and Rahnella sp. DSM 30078 were chosen as the representatives of Rahnella genomospecies 2 and genomospecies 3. Bootstrap values of neighbor-joining analysis of 1,000 replications are shown on the branches as percentages. Scale bar represents the number of substitution per nucleotide position.

and BLASTn results. Isolate PCRCB18 showed 99.9\% similarity to $R$. aquatilis CIP $78.65^{\mathrm{T}}$, while PCRCB19 isolate was closely related to Rahnella sp. WMR15 (99.9\% identity).

\section{Screening of bacterial and fungal isolates}

The formation of clear zones by fungi (12), cellulolytic bacteria (13), and bacteria isolated from SDC and CRC in this study were investigated on PSM agar plates. The cellulolytic bacteria did not produce clear zones around their colonies (data not shown). All the fungi from SDC, except the SDCF16 isolate, exhibited clear zone formation (Table 4). The fungi isolated from SDC belonged to genera Mucor (nine isolates), Penicillium (five isolates), and Galactomyces (three isolates). The fungi from CRC belonged to genera Coniochaeta (eight isolates), Fusarium (one isolate), Penicillium (one isolate), and Aspergillus (one isolate).

Among all the fungal isolates from SDC and CRC, the Penicillium isolates showed the greatest clear zone diameters (SDCF3, followed by SDCF2 and SDCF5), while the largest clear zone was formed by the Mucor isolates (SDCF18, followed by SDCF 24 and SDCF11) (Fig. 2). In the isolates from $\mathrm{CRC}$, the highest $\mathrm{CD} / \mathrm{GD}$ ratio was displayed by $\mathrm{CRCF} 1$
(Coniochaeta sp.), while CRCF27 (Fusarium sp.), CRCF11 (Aspergillus sp.), and CRCF6 (Penicillium sp.) formed greater clear zones than CRCF1. The isolates closest to Rahnella $\mathrm{sp.}$ (PCRCB18 and PCRCB19) showed higher CD/GD ratios and clear zone diameters than all other isolates (Fig. 2). Isolate PCRCB18 showed the highest ability to form clear zone. Among isolates from SDC, PSCDB1 (Pseudomonas sp.) revealed the highest $\mathrm{CD} / \mathrm{GD}$ ratio and clear zone diameter, followed by PSCDB3 and PSCDB5 (Enterobacter sp.) at similar levels.

Phytate-degrading activity was subsequently evaluated for the most effective eight fungal isolates (SDCF1, SDCF3, SDCF5, SDCF11, SDCF17, SDCF18, SDCF22, and CRCF1) in the genera Mucor, Penicillium, Galactomyces, and Coniochaeta and the most effective four bacterial isolates (PSDCB1, PSDCB3, PCRCB18, and PCRCB19), which were selected on the basis of their higher $\mathrm{CD} / \mathrm{GD}$ ratio or greater clear zone diameters. Among Mucor isolates, SDCF11 showed the highest clear zone diameter, SDCF18 showed the highest $\mathrm{CD} / \mathrm{GD}$ ratio, and SDCF22 displayed relatively high $\mathrm{CD} / \mathrm{GD}$ ratio and clear zone diameter. Isolate SDCF3 was selected because of its highest clear zone diameter, and SDCF5 was selected because it had the highest CD/GD ratio among the Penicillium isolates. Two Galactomyces isolates (SDCF1 and SDCF17) were selected for the same reason. Coniochaeta isolate $\mathrm{CRCF} 1$ showed the highest $\mathrm{CD} / \mathrm{GD}$ ratio and clear zone diameter among the Coniochaeta isolates. Four bacterial isolates (PSDCB1, PSDCB3, PCRCB18, and PCRCB19) showed higher $\mathrm{CD} / \mathrm{GD}$ ratios and the greatest clear zone diameters.

\section{Phytase activity of the selected fungi and bacteria}

Isolate SDCF1 (Galactomyces sp.) and SDCF11 (Mucor sp.) increased the concentrations of inorganic P ( 0.30 and $0.23 \mu \mathrm{mol} \mathrm{P} \mathrm{mL} \mathrm{mL}^{-1}$, respectively) more than other tested fungal isolates (Fig. 3). On the other hand, some isolates such as Penicillium isolates (SDCF3 and SDCF5) and Mucor isolates (SDCF18 and SDCF22) reduced the level of inorganic $\mathrm{P}$ in the culture medium compared to the control (medium without inoculation) after incubation. Inorganic $\mathrm{P}$ in the culture of SDCF17 (Mucor sp.) and CRCF1 (Coniochaeta sp.) increased slightly. In bacterial isolates PSDCB3 (Enterobacter sp.) showed the highest inorganic $\mathrm{P}$ in the culture filtrate, while PSDCB1 (Pseudomonas sp.) decreased the inorganic $\mathrm{P}$ concentration in the culture filtrate. Rahnella isolates (PCRCF18 and PCRCF19) exhibited similar levels of inorganic $\mathrm{P}$ concentrations to the control. Phytase activity in the culture filtrate of fungi and bacteria showed a similar tendency to the concentrations of inorganic $\mathrm{P}$ released 
Table 4. List of fungal isolates that formed or did not form clear zones around their colonies in the plate assay

\begin{tabular}{|c|c|c|c|c|c|c|c|c|}
\hline \multirow{2}{*}{ Genus } & \multicolumn{4}{|c|}{ Clear zone formed } & \multicolumn{4}{|c|}{ Clear zone not formed } \\
\hline & \multicolumn{4}{|c|}{ Isolate No. } & \multicolumn{4}{|c|}{ Isolate No. } \\
\hline Mucor & SDCF11 & SDCF14 & SDCF18 & SDCF19 & & & & \\
\hline & SDCF20 & SDCF21 & SDCF22 & SDCF24 & & & & \\
\hline & SDCF25 & & & & & & & \\
\hline Penicillium & SDCF2 & SDCF3 & SDCF5 & SDCF6 & CRCF12 & & & \\
\hline & SDCF23 & CRCF6 & & & & & & \\
\hline Galactomyces & SDCF1 & SDCF10 & SDCF17 & & & & & \\
\hline Coniochaeta & CRCF1 & CRCF7 & CRCF17 & CRCF21 & CRCF20 & CRCF24 & CRCF30 & \\
\hline & CRCF22 & CRCF23 & CRCF29 & CRCF31 & & & & \\
\hline Trichoderma/Hypocrea & & & & & CRCF2 & CRCF3 & CRCF8 & CRCF9 \\
\hline & & & & & CRCF10 & CRCF13 & CRCF14 & CRCF15 \\
\hline & & & & & CRCF16 & CRCF18 & CRCF28 & CRCF4 \\
\hline & & & & & CRCF5 & CRCF26 & & \\
\hline Aspergillus & CRCF11 & & & & SDCF16 & & & \\
\hline Fusarium & CRCF27 & & & & & & & \\
\hline
\end{tabular}
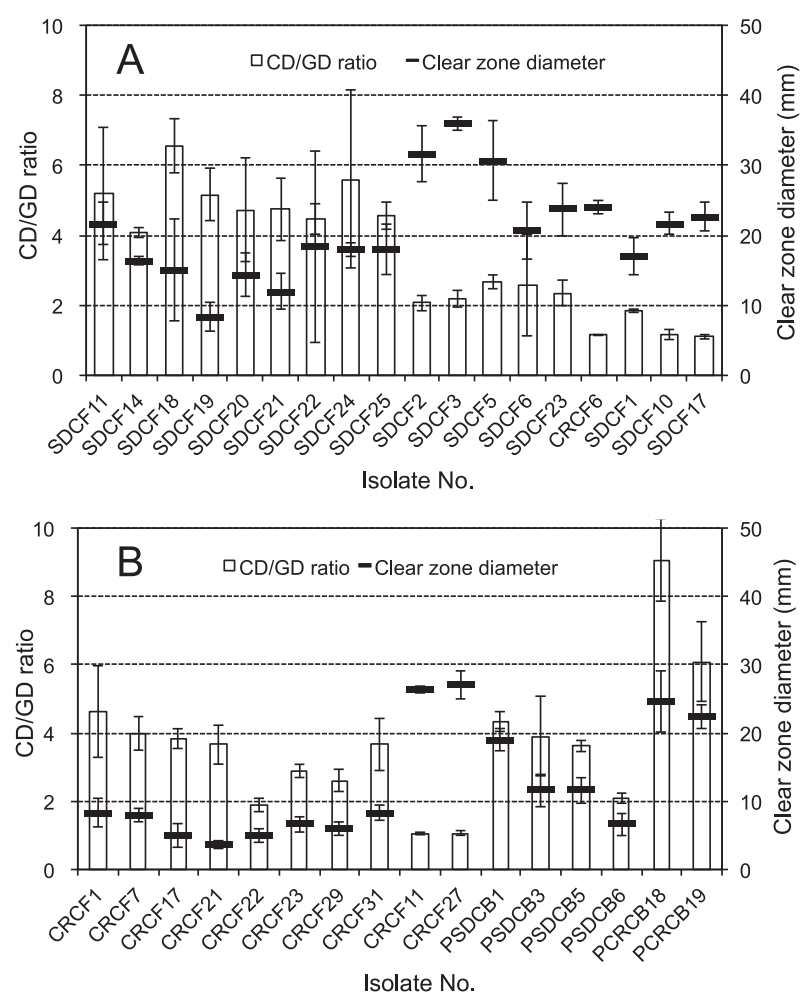

Fig. 2. Clear zone diameter and $\mathrm{CD} / \mathrm{GD}$ ratio of fungi and bacteria isolated from $\mathrm{SDC}$ and $\mathrm{CRC}$ in the plate assay. $\mathrm{CD} / \mathrm{GD}$ ratio is the ratio of the clear zone diameter to growth diameter. Clear zone diameters around the colonies are presented in $\mathrm{mm}$. Vertical bars indicate the standard deviations. Panel A shows results of Mucor sp. SDCF11, 14, 18, 19, 20, 21, 22, 24 and 25, Penicillium sp. SDCF2, 3, 5, 6, 23 and CRCF6, and Galactomyces sp. SDCF1, 10 and 17. Panel B shows the results of Coniochaeta sp. CRCF1, 7, 17, 21, 22, 23, 29 and 31, Aspergillus sp. CRCF11, Fusarium sp. CRCF27, Pseudomonas sp. PSDCB1, Enterobacter sp. PSDCB3 and 5, Chitinophaga sp. PSDCB6, and Rahnella sp. PCRCB18 and 19.

from sodium phytate (Fig. 3). The highest phytase activity $\left(0.0020 \mu \mathrm{mol} P\right.$ released $\left.\mathrm{min}^{-1} \mathrm{~mL}^{-1}\right)$ in fungal culture was revealed by SDCF1 (Galactomyces sp.) followed by SDCF11 (Mucor sp.) $\left(0.0019 \mu \mathrm{mol} P\right.$ released $\left.\mathrm{min}^{-1} \mathrm{~mL}^{-1}\right)$. Meanwhile SDCF17 (Galactomyces sp.), SDCF3 and SDCF5 (Penicillium sp.) showed nearly equal levels of phytase

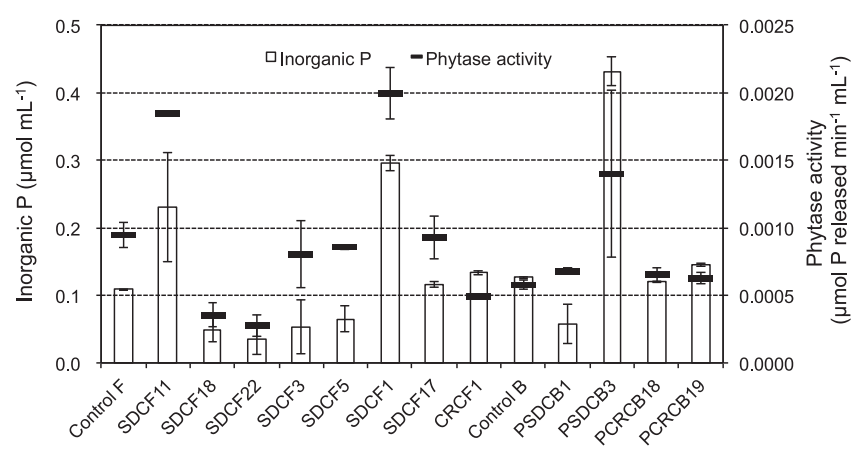

Isolate No.

Fig. 3. Inorganic $P$ concentrations and phyatase activity in the culture filtrates of selected fungal and bacterial isolates grown in liquid media containing sodium phytate as sole P source. Vertical bars indicate the standard deviations. Legend: Control F, no fungal inoculation; Control B, no bacterial inoculation; SDCF11, 18 and 22, Mucor sp.; SDCF3 and 5, Penicillium sp.; SDCF1 and 17, Galactomyces sp.; CRCF1, Coniochaeta sp; PSDCB1, Pseudomonas sp.; PSDCB3, Enterobacter sp.; PSDCB18 and 19, Rahnella sp.

activity to the control, and the activity of Mucor isolates (SDCF18 and SDCF 22) and Coniochaeta isolate (CRCF1) was low. The bacterial isolate PSDCB3 (Enterobacter sp.) displayed higher phytase activity $(0.0014 \mu \mathrm{mol} \mathrm{P}$ released $\left.\mathrm{min}^{-1} \mathrm{~mL}^{-1}\right)$ than the other bacterial isolates. Other bacterial isolates, PSDCB1 (Pseudomonas sp.), PSDCB18, and PCRCB19 (Rahnella sp.), showed activity at the similar level to the control.

\section{Degradation of phytate in organic materials inoculated with} the selected fungi and bacteria

During incubation with selected fungal isolates, the phytate $P$ contents of the organic materials were reduced in comparison with the control treatment, as illustrated in Fig. 4. The most active isolates concerning the degradation of phytate were Penicillium isolates (SDCF3 and SDCF5). The phytate $\mathrm{P}$ levels of organic materials inoculated by SDCF3 and SDCF5 were reduced by 88.3 and $87.8 \%$, respectively, after $7 \mathrm{~d}$ and by 98.4 and $99.2 \%$, respectively, after $14 \mathrm{~d}$. The amounts of decreased phytate $P$ were 6.68 and $6.64 \mathrm{mg}$ flask $^{-1}$ after $7 \mathrm{~d}$ and 7.68 and $7.74 \mathrm{mg} \mathrm{flask}^{-1}$ after $14 \mathrm{~d}$, as 

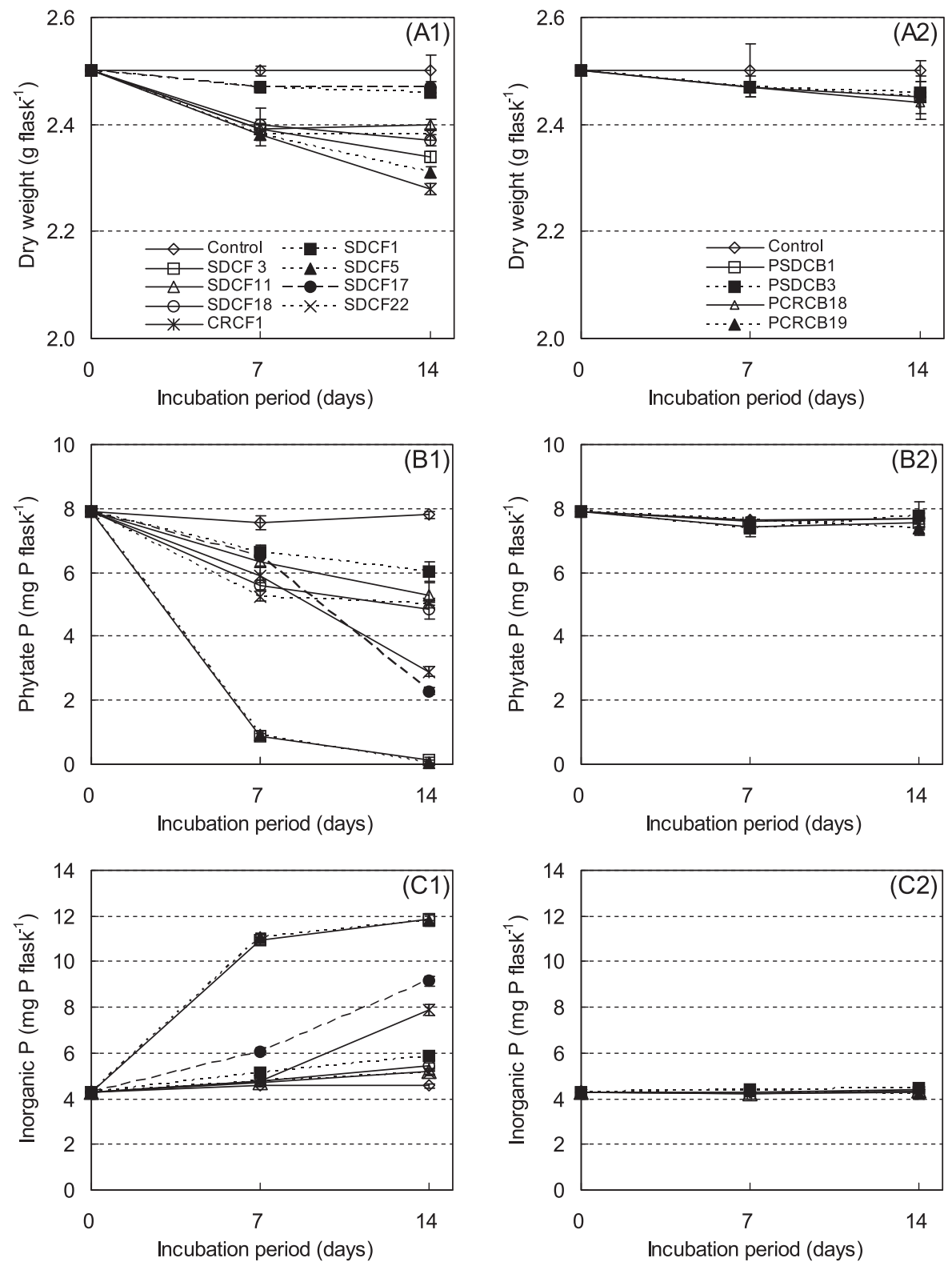

Fig. 4. Changes in dry weight, phytate $P$ and inorganic $P$ contents of organic materials inoculated with isolates of fungi (A1, B1 and, C1) and bacteria (A2, B2 and, C2) during incubation. Vertical bars indicate the standard deviations. SDCF1 and 17, Galactomyces sp.; SDCF3 and 5, Penicillium sp.; SDCF11, 18 and 22, Mucor sp.; CRCF1, Coniochaeta sp.; PSDCB1, Pseudomonas sp.; PSDCB3, Enterobacter sp.; PSDCB18 and 19, Rahnella sp.

compared with the amount of phytate $\mathrm{P}$ in the control. Galactomyces sp. SDCF1 exhibited the lowest decomposing rate, where phytate $\mathrm{P}$ was reduced by $23.0 \%$ over a $14-\mathrm{d}$ period; however, another Galactomyces sp., SDCF17, reduced phytate $\mathrm{P}$ by $13.9 \%$ and $71.6 \%$, in comparison with that in the control after 7 and $14 \mathrm{~d}$ of incubation, respectively. Coniochaeta sp. CRCF1 exhibited relatively high phytate degradation ability, which mineralized 21.9 and $63.0 \%$ phytate $\mathrm{P}$ after 7 and $14 \mathrm{~d}$, respectively. The phytate degradation ability of Mucor isolates (SDCF11, SDCF18, and SDCF22) was relatively low, since they reduced phytate $\mathrm{P}$ by $34.7,37.9$, and $35.3 \%$, respectively, after $14 \mathrm{~d}$. The dry weights of organic materials were reduced differently by the growth of fungal isolates. The amount of dry weight loss by fungal isolates was similar at $4.0-4.8 \%$ after $7 \mathrm{~d}$ of incubation, except for Galactomyces isolates (SDCF1 and SDCF17); however, Coniochaeta sp. CRCF1 and Penicillium sp. SDCF5 showed the greatest decrease in dry weight of organic materials ( 8.8 and $7.6 \%$, respectively) after $14 \mathrm{~d}$. The decrease in dry weight by 2 Galactomyces isolates (SDCF1 and SDCF17) was lowest, at 1.6 and $1.2 \%$, respectively, after 14 d (Fig. 4).

The concentrations of inorganic $\mathrm{P}$ were increased by inoculation with fungal isolates (Fig. 4), which reflected the reduction of phytate $\mathrm{P}$ contents. Penicillium isolates (SDCF3 and SDCF5) displayed the highest inorganic $\mathrm{P}$ (11.9 and $11.8 \mathrm{mg} \mathrm{P}$ flask $^{-1}$, respectively) compared to the control (4.6 mg P flask $^{-1}$ ) after $14 \mathrm{~d}$ of incubation. The inorganic P levels of isolates SDCF3 and SDCF5 (Penicillium sp.) sharply increased until $7 \mathrm{~d}$ after treatment. In comparison, 
Galactomyces sp. SDCF17 and Coniochaeta sp. CRCF1 showed low efficiency in the degradation of phytate during the first week of incubation and effectively increased inorganic $\mathrm{P}$ over the second week. The other isolates, including Mucor and Galactomyces spp., did not show a noticeable increase in inorganic $\mathrm{P}$ content during incubation.

The bacterial isolates incubated with organic materials scarcely decreased the dry weights of the organic materials and did not decrease phytate $\mathrm{P}$ or increase inorganic $\mathrm{P}$ contents in organic materials (Fig. 4).

\section{Discussion}

Isolates PSDCB1, PSDCB3, PSDCB5, PSDCB6, PCRCB18, and PCRCB19 were closest to Pseudomonas extremaustralis, Enterobacter nimipressuralis, Enterobacter amnigenus, Chitinophaga arvensicola, Rahnella aquatilis, and Rahnella sp. WMR15, respectively (Fig. 1). Although $R$. aquatilis is the only species belonging to the genus of Rahnella, three genome species of the genus of Rahnella, such as $R$. aquatilis, Rahnella genomospecies 2, and Rahnella genomospecies 3, which cannot be phenotypically differentiated, have been previously reported $(6,52)$. Isolate PCRCB19 was closest to Rahnella sp. WMR15 (52), which is a representative of Rahnella genomospecies 2 , based on phylogenetic analysis. The bacteria species in these four genera have been widely found in composts. Several species of Enterobacter and Pseudomonas have been isolated from the active phase of compost $(4,10)$. In addition, Manjunathan and Kaviyarasan (41) found that bacteria members of the genera Pseudomonas and Enterobacter were dominant during the composting of sawdust and wheat bran. Rahnella sp. was detected during the degradation of the mixture of sewage sludge and food waste (27), and during aerobic degradation of dairy cattle dung (16). C. arvensicola was isolated from acidic Sphagnum peatlands (45), and C. eiseniae was isolated from vermicompost (64).

Phytase activity by various bacteria, including genera such as Bacillus, Citobacter, Escherichia, Enterobacter, Klebsiella, and Pseudomonas, has been subjected to review (31). The phytate-utilizing ability of several bacterial isolates during the aerobic degradation of dairy cattle dung, which belong to genera Bacillus, Enterobacter, Escherichia, Shigella, Streptomyces, Rahnella, and Ochrobactrum, has been reported using the PSM plate assay (16); however, degradation of phytate by Chitinophaga sp. has not been reported.

The fungal isolates that exhibited clear zone formation in the plate assay belonged to genera Mucor, Penicillium, Galactomyces, Coniochaeta, Fusarium, and Aspergillus (Table 4). Mucor spp. have been commonly reported for phytate degradation $(3,51)$. For instance, Howson and Davis (25) described the phytase activities of several fungal genera including Aspergillus, Mucor, and Geotrichum (teleomorph: Galactomyces) (9). The production of phytase by Penicillium and Fusarium has also been documented $(42,57)$; however, reports of phytate degradation by Coniochaeta sp. could not be found. Although the phytase activity of Trichoderma spp., such as T. harzianum and T. viride, was indicated by Aseri et al. (1), isolates belonging to the Trichoderma genus did not exhibit any ability to form a clear zone around their colonies in this study.

Among all the tested fungi from SDC and CRC, Penicillium sp. (SDCF3, followed by SDCF2 and SDCF5) showed the greatest clear zones, while the highest $\mathrm{CD} / \mathrm{GD}$ ratio was revealed by Mucor sp. (SDCF18, SDCF 24, and SDCF11) (Fig. 2). The ability to form a clear zone by isolates from CRC was lower than from SDC. Among the isolates from $\mathrm{CRC}$, the highest $\mathrm{CD} / \mathrm{GD}$ ratio was observed in CRCF1 (Coniochaeta sp.). Isolates CRCF27 (Fusarium sp.), CRCF11 (Aspergillus sp.), and CRCF6 (Penicillium sp.) formed greater clear zones than CRCF1. Rahnella spp. (PCRCB18 and PCRCB19) created a higher CD/GD ratio and larger clear zones than other bacteria (Fig. 2), while PCRCB18 showed the largest clear zone. PSCDB1 (Pseudomonas sp.), followed by PSCDB3 and PSCDB5 (Enterobacter sp.), had moderate ability. No cellulolytic bacteria isolated from SDC and CRC (13), which belong to the genera of Streptomyces, Microbispora, Paenibacillus, and Cohnella, formed clear zones around their colonies in the plate assay (data no shown). There has been no report regarding the production of phytase by genera Microbispora and Cohnella. López-López et al. (39) identified Streptomyces kunmingensis as one of the phytate-degrading bacteria; however, isolates of Streptomyces sp. from SDC and CRC in the current study did not form clear zones. The two Paenibacillus isolates also did not form clear zones, although a phytase-like protein of Paenibacillus was encoded (32). These variations may be caused by differences among identified species.

The highest phytase activity in liquid medium was revealed by SDCF1 (Galactomyces sp.) and SDCF11 (Mucor sp.) (Fig. 3 ). The increases in the concentrations of inorganic $P$ in the culture filtrates revealed by Galactomyces and Mucor isolates were owing to the higher phytase activity. Some isolates belonging to genera Mucor and Penicillium reduced inorganic $\mathrm{P}$ content in the liquid medium. This result may be caused by the uptake of inorganic $\mathrm{P}$ in the growth of fungal isolates. Phytase activity and inorganic $\mathrm{P}$ in culture filtrates of liquid media inoculated with selected fungal and bacterial isolates did not show a relationship with their $\mathrm{CD} / \mathrm{GD}$ ratio and clear zone diameters.

The highest degrading ability of phytate in organic materials among fungi was revealed by Penicillium isolates SDCF3 and SDCF5 (Fig. 4), which might be due to their larger production of phytase. In addition, their greater growth levels might have been supported by cellulolytic and hemicellulolytic abilities, such as cellulase, xylanase, $\beta$ glucanase, and mannanase activities (12), as shown by the higher decrease of dry weight. In contrast, Galactomyces isolates, which did not show any cellulolytic or hemicellulolytic activities (12), showed the lowest loss of dry weight; however, Galactomyces isolate SDCF17 degraded phytate in large quantities (after that of Penicillium isolates) after $14 \mathrm{~d}$ of incubation. Meanwhile, Galactomyces isolate SDCF1 decomposed the smallest amount of phytate among all tested fungi. Phytase production might be related to a combination of growth, different species, and strains. Although a higher production of phytase by Mucor spp. such as $M$. racemosus and $M$. hiemalis has been reported $(3,5$, 51), Mucor isolates (SDCF11, SDCF18, and SDCF22), which 
Table 5. Correlation coefficients between clear zone diameters and the ratio of clear zone diameter to growth diameter (CD/GD ratio) in the plate assay with fungal isolates, phytase activity and inorganic $\mathrm{P}$ in culture filtrate, and phytate $\mathrm{P}$ and inorganic $\mathrm{P}$ contents in organic materials inoculated with fungal isolates after incubation

\begin{tabular}{|c|c|c|c|c|c|c|}
\hline & Clear zone diameter & $\mathrm{CD} / \mathrm{GD}$ ratio & $\begin{array}{c}\text { Phytate P } \\
\text { (7d) }\end{array}$ & $\begin{array}{c}\text { Phytate P } \\
\text { (14 d) }\end{array}$ & $\begin{array}{c}\text { Inorganic P } \\
(7 \mathrm{~d})\end{array}$ & $\begin{array}{c}\text { Inorganic P } \\
(14 d)\end{array}$ \\
\hline Clear zone diameter & 1 & & & & & \\
\hline $\mathrm{CD} / \mathrm{GD}$ ratio & $-0.5058(P=0.2009)$ & 1 & & & & \\
\hline Phytate P (7 d) & $-0.8022(P=0.0166)^{*}$ & $0.2472(P=0.5550)$ & 1 & 1 & & \\
\hline Phytate P (14 d) & $-0.6854(P=0.0606)$ & $0.4516(P=0.2614)$ & $0.8278(P=0.0112)^{*}$ & 1 & & \\
\hline Inorganic $\mathrm{P}(7 \mathrm{~d})$ & $0.8770(P=0.0042)^{*}$ & $-0.4937(P=0.2137)$ & $-0.9513(P=0.0003)^{*}$ & * $-0.8858(P=0.0034)^{*}$ & 1 & \\
\hline Inorganic $\mathrm{P}(14 \mathrm{~d})$ & $0.7273(P=0.0409)^{*}$ & $-0.5968(P=0.1183)$ & $-0.8161(P=0.0135)^{*}$ & * $-0.9771(P<0.0001)^{*}$ & $0.9187(P=0.0013)^{*}$ & 1 \\
\hline
\end{tabular}

* Significant correlation at $P<0.05$.

were closest to $M$. circinelloides (12), revealed relatively low phytate degradation ability in this study, and a moderate reduction of dry weight. This difference may be caused by different species. Mucor isolates (SDCF11, SDCF18, and SDCF22) showed $\beta$-glucanase and mannanase activities, but not cellulase or xylanase activities (12). In addition, it should be mentioned that the difference in decreased phytate $\mathrm{P}(2.50$, 2.95 , and $2.76 \mathrm{mg} \mathrm{P}^{\mathrm{P}}$ flask $\left.^{-1}\right)$ and increased inorganic $\mathrm{P}(0.65$, 0.86 , and $0.56 \mathrm{mg} \mathrm{P}$ flask $^{-1}$ ) levels in the organic materials inoculated with Mucor isolates (SDCF11, SDCF18, and SDCF22) were markedly larger than other fungal isolates. James and Casida (28) reported that M. racemosus could accumulate $5-6 \%$ phosphorus in its dry mycelium, and approximately $58 \%$ phosphorus in the mycelium existed as inorganic polyphosphate. Coniochaeta isolate CRCF1 showed higher degradation ability than Mucor isolates, and the largest loss in dry weight in the incubation experiment, even though reports about phytate degradation by Coniochaeta could not be found. Coniochaeta isolate CRCF1 exhibited xylanase, $\beta$-glucanase, and mannanase activities (12). The cellulolytic and hemicellulolytic abilities of fungi could help their growth in organic materials. The degradation ability of phytate in organic materials inoculated with selected fungi, however, did not show the relationship with their phytase activities in liquid culture. The measurement of phytase activity using liquid culture should be further investigated.

Previous studies have also reported that phytase production is affected by the components of the media, including the concentration of inorganic $\mathrm{P}$ and phytate in the media $(3,11$, $14,17,20,26,34,36,46,54)$. The effects of inorganic $\mathrm{P}$ and phytate concentration on the induction of phytase production vary among microorganisms. Fredrikson et al. (14) reported that calcium phytate in the PSM was hydrolyzed to inorganic orthophosphate by autoclaving. The highest phytate degradation by Rhizopus microsporus, Aspergillus ficuum, and Geotrichum candidum was observed using synthetic liquid medium containing both inorganic $\mathrm{P}$ and phytate, which indicates that inorganic $\mathrm{P}$ might facilitate initial microbial growth and an increase of phytase activity following the decrease of inorganic $\mathrm{P}$ (14). In comparison, phytase synthesis by fungi decreased markedly when increasing amounts of phosphate were added to the medium, while the growth of microbes increased with increased phosphate (3, 11, 17, 25, 46, 54); however, the concentrations of inorganic $\mathrm{P}$ that limited the induction of phytase differed among species and strains. A similar phenomenon was observed for bacteria, such as Bacillus laevolacticus (20) and Mitsuokella jalaludinii (36). In the case of B. subtilis VTT E-68013, the medium containing inorganic phosphate and phytate did not induce phytase production; however, synthetic medium containing phytate as the sole $\mathrm{P}$ source could induce it, indicating that the synthesis of phytase might be regulated by a combination of phytate and limiting inorganic P (34).

The ability of fungal isolates to degrade phytate was evaluated using the clear zone diameter and $\mathrm{CD} / \mathrm{GD}$ ratio, because their growth obviously affected the clear zone diameter; however, the $\mathrm{CD} / \mathrm{GD}$ ratio was not significantly correlated with the clear zone diameter $(\mathrm{R}=-0.5058$; $P=0.2009)$, phytate $\mathrm{P}(\mathrm{R}=0.2472 ; P=0.5550, \mathrm{R}=0.4516$; $P=0.2614)$, or inorganic $\mathrm{P}(\mathrm{R}=-0.4937 ; P=0.2137, \mathrm{R}=-0.5968$; $P=0.1183)$. The significantly negative correlation between the clear zone diameter and phytate $\mathrm{P}$ after $7 \mathrm{~d}$, and the significantly positive correlations between the clear zone diameter and inorganic P after 7 and $14 \mathrm{~d}$ demonstrated that the growth of fungi might have a major effect on the degradation of phytate in organic materials, as well as phytase-producing ability, although other types of organic materials were not tested in this study (Table 5). Furthermore, there were significantly negative correlations between phytate $\mathrm{P}$ and inorganic $\mathrm{P}$ after incubation. Hence, the clear zone diameter in the PSM plate assay might be a more useful method to estimate the ability to degrade phytate in fungal studies, rather than the $\mathrm{CD} / \mathrm{GD}$ ratio.

Bacterial isolates that were applied in the incubation experiment did not display any significant activity on phytate degradation of the organic materials (Fig. 4), although the bacterial isolate PSDCB3 (Enterobacter sp.) showed phytase activity in liquid culture. The lack of a useable carbon source for bacterial isolates may cause less growth, while sufficient amounts of inorganic $\mathrm{P}$ in organic materials may affect phytase production. The phytase activity of bacterial isolates other than PSDCB3 should be confirmed under different conditions.

In conclusion, fungi probably play a major role in phytate degradation during the composting process since fungal isolates selected by the PSM plate assay degraded phytate in organic materials, but selected bacterial isolates did not. Two Penicillium sp., SDCF3 and SDCF5, showed the highest degradation ability of phytate, and Coniochaeta isolate CRCF1 exhibited the highest degradation ability of organic materials and relatively high degradation ability of phytate, suggesting their considerable role during composting. This is the first report about phytate degradation by Coniochaeta sp. 


\section{Acknowledgements}

We are extremely grateful to the Egyptian government for providing financial assistance to the first author.

\section{References}

1. Aseri, G.K., N. Jain, and J.C. Tarafdar. 2009. Hydrolysis of organic phosphate forms by phosphatases and phytase producing fungi of arid and semiarid soils of India. Am.-Eurasian. J. Agric. Environ. Sci. 5:564-570.

2. Ashley, K., D. Cordell, and D. Mavinic. 2011. A brief history of phosphorus: From the philosopher's stone to nutrient recovery and reuse. Chemosphere 84:737-746.

3. Bogar, B., G. Szakacs, A. Pandey, S. Abdulhameed, J.C. Linden, and R.P. Tengerdy. 2003. Production of phytase by Mucor racemosus in solid-state fermentation. Biotechnol. Prog. 19:312-319.

4. Boulter, J.I., J.T. Trevors, and G.J. Boland. 2002. Microbial studies of compost: bacterial identification, and their potential for turfgrass pathogen suppression. World J. Microbiol. Biotechnol. 18:661-671.

5. Boyce, A., and G. Walsh. 2007. Purification and characterisation of an acid phosphatase with phytase activity from Mucor hiemalis Wehmer. J. Biotechnol. 132:82-87.

6. Brenner, D.J., H.E. Müller, A.G. Steigerwalt, A.M. Whitney, C.M O'Hara, and P. Kämpfer. 1998. Two new Rahnella genomospecies that cannot be phenotypically differentiated from Rahnella aquatilis. Int. J. Syst. Bacteriol. 48:141-149.

7. Celi, L., S. Lamacchia, F.A. Marsan, and E. Barberis. 1999. Interaction of inositol hexaphosphate on clays: adsorption and charging phenomena. Soil Sci. 164:574-585.

8. Dao, T.H. 2003. Polyvalent cation effects on myo-inositol hexakis dihydrogenphosphate enzymatic dephosphorylation in dairy wastewater. J. Environ. Qual. 32:694-701.

9. de Hoog, G.S., and M.T. Smith. 2004. Ribosomal gene phylogeny and species delimitation in Geotrichum and its teleomorphs. Stud. Mycol. 50:489-515.

10. Droffner, M., I. Brintonjr, and E. Vans. 1995. Evidence for the prominence of well characterized mesophilic bacteria in thermophilic $\left(50-70^{\circ} \mathrm{C}\right)$ composting environments. Biomass Bioenerg. 8:191-195.

11. Ebune, A., S. Al-Asheh, and Z. Duvnjak. 1995. Effects of phosphate, surfactants and glucose on phytase production and hydrolysis of phytic acid in canola meal by Aspergillus ficuum during solid-state fermentation. Bioresour. Technol. 54:241-247.

12. Eida, M.F., T. Nagaoka, J. Wasaki, and K. Kouno. 2011. Evaluation of cellulolytic and hemicellulolytic abilities of fungi isolated from coffee residue and sawdust composts. Microbes Environ. 26:220 227.

13. Eida, M.F., T. Nagaoka, J. Wasaki, and K. Kouno. 2012. Isolation and characterization of cellulose-decomposing bacteria inhabiting sawdust and coffee residue composts. Microbes Environ. 27:226233.

14. Fredrikson, M., T. Andlid, A. Haikara, and A.-S. Sandberg. 2002. Phytate degradation by micro-organisms in synthetic media and pea flour. J. Appl. Microbiol. 93:197-204.

15. Fuentes, B., N. Bolan, R. Naidu, and M. de la Luz Mora. 2006. Phosphorus in organic waste-soil systems. J. Soil Sci. Plant. Nutr. 6:64-83.

16. Fuentes, B., M. Jorquera, and M. de la Luz Mora. 2009. Dynamics of phosphorus and phytate-utilizing bacteria during aerobic degradation of dairy cattle dung. Chemosphere 74:325-331.

17. Gargova, S., Z. Roshkova, and G. Vancheva. 1997. Screening of fungi for phytase production. Biotechnol. Tech. 11:221-224.

18. George, T.S., A.E. Richardson, and R.A. Simpson. 2005. Behaviour of plant-derived extracellular phytate upon addition to soil. Soil Biol. Biochem. 37:977-988.

19. Godoy, S., C. Chicco, F. Meschy, and F. Requena. 2005. Phytic phosphorus and phytase activity of animal feed ingredients. Interciencia 30:24-28.

20. Gulati, H.K., B.S. Chadha, and H.S. Saini. 2007. Production and characterization of thermostable alkaline phytase from Bacillus laevolacticus isolated from rhizosphere soil. J. Ind. Microbiol. Biotechnol. 34:91-98.
21. He, Z., C.W. Honeycutt, T. Zhang, and P.M. Bertsch. 2006. Preparation and FT-IR characterization of metal phytate compounds. J. Environ. Qual. 35:1319-1328.

22. Heuer, H., M. Krsek, P. Baker, K. Smalla, and E.M.H. Wellington. 1997. Analysis of actinomycete communities by specific amplification of genes encoding 16S rRNA and gel-electrophoretic separation in denaturing gradients. Appl. Environ. Microbiol. 63:3233-3241.

23. Hill, J.E., D. Kysela, and M. Elimelech. 2007. Isolation and assessment of phytate-hydrolysing bacteria from the DelMarVa Peninsula. Environ. Microbiol. 9:3100-3107.

24. Holford, I.C.R. 1997. Soil phosphorus: its measurement, and its uptake by plants. Aust. J. Soil Res. 35:227-240.

25. Howson, S.J., and R.P. Davis. 1983. Production of phytatehydrolysing enzyme by some fungi. Enzyme Microb. Technol. 5:377-382.

26. Irving, G.C.J., and M.J. McLaughlin. 1990. A rapid and simple field test for phosphorous in Olsen and Bray No.1 extracts of soil. Commun. Soil Sci. Plant Anal. 21:2245-2255.

27. Ivanov, V.N., J.Y. Wang, O.V. Stabnikova, S.T.L. Tay, and J.H. Tay. 2004. Microbiological monitoring in the biodegradation of sewage sludge and food waste. J. Appl. Microbiol. 96:641-647.

28. James, A.W., and L.E. Casida. 1964. Accumulation of phosphorus compounds by Mucor racemosus. J. Bacteriol. 37:150-164.

29. Javed, M.M., W. Ahmed, S. Zahoor, and Ikram-Ul-Haq. 2010. Solid state culturing of thermophilic fungi for phytase production. Pak. J. Bot. 42:3605-3611.

30. Jorquera, M.A., M.T. Hernández, Z. Rengel, P. Marschner, and M. de la Luz Mora. 2008. Isolation of culturable phosphobacteria with both phytate-mineralization and phosphate-solubilization activity from the rhizosphere of plants grown in a volcanic soil. Biol. Fertil. Soils. 44:1025-1034

31. Jorquera, M.A., O. Martínez, F. Maruyama, P. Marschner, and M. de la Luz Mora. 2008. Current and future biotechnological application of bacterial phytase and phytase-producing bacteria. Microbes Environ. 23:182-191.

32. Jorquera, M.A., D.E. Crowley, P. Marschner, R. Greiner, M.T. Fernández, D. Romero, D. Menezes-Blackburn, and M. de la Luz Mora. 2011. Identification of $\beta$-propeller phytase-encoding genes in culturable Paenibacillus and Bacillus spp. from the rhizosphere of pasture plants on volcanic soils. FEMS Microbiol. Ecol. 75:163-172.

33. Kanazawa, S., Y. Ishikawa, K. Tomita-Yokotani, et al. 2008. Space agriculture for habitation on Mars with hyper-thermophilic aerobic composting bacteria. Adv. Space Res. 41:696-700.

34. Kerovuo, J., L. Marko, P.N. Lauraeus, K. Nisse, and A. Juha. 1998. Isolation, characterization, molecular gene cloning, and sequencing of a novel phytase from Bacillus subtilis. Appl. Environ. Microbiol. 64:2079-2085.

35. Konietzny, U., and R. Greiner. 2002. Molecular and catalytic properties of phytate-degrading enzymes (phytases). Int. J. Food Sci. Technol. 37:791-812.

36. Lan, G.Q., N. Abdullah, S. Jallaludin, and Y.W. Ho. 2002. Culture conditions influencing phytase production of Mitsuokella jalaludinii, a new bacterial species from the rumen of cattle. J. Appl. Microbiol. 93:668-674.

37. Lane, D.J. 1991. 16S/23S rRNA sequencing, p. 115-175. In E. Stackebrandt, and M. Goodfellow (ed.), Nucleic Acid Techniques in Bacterial Systematics. John Wiley and Sons, New York.

38. Lopez, M.J., M.D. Vargas-Garcia, F. Suarez-Estrella, N.N. Nichols, B.S. Dien, and J. Moreno. 2007. Lignocellulose-degrading enzymes produced by the ascomycete Coniochaeta ligniaria and related species: Application for a lignocellulosic substrate treatment. Enzyme Microb. Technol. 40:794-800.

39. López-López, A., M.A. Rogel, E. Ormeño-Orrillo, J. MartínezRomero, and E. Martínez-Romero. 2010. Phaseolus vulgaris seedborne endophytic community with novel bacterial species such as Rhizobium endophyticum sp. nov. Syst. Appl. Microbiol. 33:322-327.

40. Lung, S.-C., and B.L. Lim. 2006. Assimilation of phytate-phosphorus by the extracellular phytase activity of tobacco (Nicotiana tabacum) is affected by the availability of soluble phytate. Plant Soil 279:187199.

41. Manjunathan, J., and V. Kaviyarasan. 2011. Bacteria associated with compost used for cultivation of Indian edible mushroom Lentinus tuber-regium (Fr.). Int. J. Eng. Sci. Technol. 3:44-51. 
42. Marlida, Y., R. Delfita, P. Adnadi, and G. Ciptaan. 2010. Isolation, characterization and production of phytase from endophytic fungus its application for feed. Pak. J. Nutr. 9:471-474.

43. Murphy, J., and J.P. Riley. 1962. A modified single solution method for the determination of phosphate in natural waters. Anal. Chim. Acta. 27:31-36.

44. Pandey, A., G. Szakacs, C.R. Soccol, J.A. Rodriguez-Leon, and V.T. Soccol. 2001. Production, purification and properties of microbial phytases. Bioresour. Technol. 77:203-214.

45. Pankratov, T.A., I.S. Kulichevskaya, W. Liesack, and S.N. Dedysh. 2006. Isolation of aerobic, gliding, xylanolytic and laminarinolytic bacteria from acidic Sphagnum peatlands and emended description of Chitinophaga arvensicola Kämpfer et al. 2006. Int. J. Syst. Evol. Microbiol. 56:2761-2764.

46. Quan, C., L. Zhang, Y. Wang, and Y. Ohta. 2001. Production of phytase in a low phosphate medium by a novel yeast Candida krusei. J. Biosci. Bioeng. 92:154-160.

47. Raboy, V., D.B. Dickinson, and M.G. Neuffer. 1990. A survey of survey of maize kernel mutants for variation in phytic acid. Maydica 35:383-390.

48. Ravindran, V., G. Ravindran, and S. Sivalogan. 1994. Total and phytate phosphorus contents of various foods and feedstuffs of plant origin. Food Chem. 50:133-136.

49. Reale, A., L. Mannina, P. Tremonte, A.P. Sobolev, M. Succi, E. Sorrentino, and R. Coppola. 2004. Phytate degradation by lactic acid bacteria and yeasts during the wholemeal dough fermentation: a ${ }^{13} \mathrm{P}$ NMR study. J. Agric. Food Chem. 52:6300-6305.

50. Richardson, A.E., T.S. George, M. Hens, and R.J. Simpson. 2005 Utilization of soil organic phosphorus by higher plants, p. 165-184. In B.L. Turner, E. Frossard, and D. Baldwin (ed.), Organic Phosphorus in the Environment. CABI Publishing, Wallingford.

51. Roopesh, K., S. Ramachandran, K.M. Nampoothiri, G. Szakacs, and A. Pandey. 2006. Comparison of phytase production on wheat bran and oilcakes in solid-state fermentation by Mucor racemosus. Bioresour. Technol. 97:506-511.

52. Rozhon, W.M., E.K. Petutschnig, and C. Jonak. 2006. Isolation and characterization of pHW15, a small cryptic plasmid from Rahnella genomospecies 2. Plasmid 56:202-215.

53. Schachtman, D.P., J.R. Robert, and S.M. Ayling. 1998. Phosphorus uptake by plants: from soil to cell. Plant Physiol. 116:447-453.

54. Shieh, T.R., and J.H. Ware. 1968. Survey of Microorganisms for the production of extracellular phytase. Applied Miclobiol. 16:348-1351.
55. Tamura, K., D. Peterson, N. Peterson, G. Stecher, M. Nei, and S. Kumar. 2011. MEGA5: Molecular evolutionary genetics analysis using maximum likelihood, evolutionary distance, and maximum parsimony methods. Mol. Biol. Evol. 28:2731-2739.

56. Tangsubkul, N., S. Moore, and T.D. Waite. 2005. Incorporating phosphorus management considerations into wastewater management practices. Environ. Sci. Pol. 8:1-15.

57. Tseng, Y.-H., T.J. Fang, and S.-M. Tseng. 2000. Isolation and characterization of a novel phytase from Penicillium simplicissimum. Folia Microbiol. 45:121-127.

58. Tuomela, M., M. Vikman, A. Hatakka, and M. Itävaara. 2000. Biodegradation of lignin in a compost environment: a review. Bioresour. Technol. 72:169-183.

59. Turner, B.L., M.J. Papházy, P.M. Haygarth, and I.D. McKelvie. 2002. Inositol phosphate in the environment. Phi. Trans. R. Soc. B. 357:449-469.

60. Turner, S., K.M. Pryer, V.P.W. Miao, and J.D. Palmer. 1999. Investigating deep phylogenetic relationships among cyanobacteria and plastids by small subunit rRNA sequence analysis. J. Eukaryot. Microbiol. 46:327-338.

61. Wyss, M., R. Brugger, A. Kronenberger, R. Rémy, R. Fimbel, G. Oesterhelt, M. Lehmann, and A.P.G.M. Van Loon. 1999. Biochemical characterization of fungal phytases (myo-inositol hexakisphosphate phosphohydrolases): catalytic properties. Appl. Environ. Microbiol. 65:367-373.

62. Wickramatilake, A.R.P., K. Kouno, and T. Nagaoka. 2010. Compost amendment enhances the biological properties of Andosols and improves phosphorus utilization from added rock phosphate. Soil Sci. Plant Nutr. 56:607-616.

63. Wickramatilake, A.R.P., R. Munehiro, T. Nagaoka, J. Wasaki, and K. Kouno. 2011. Compost amendment enhances population and composition of phosphate solubilizing bacteria and improves phosphorus availability in granitic regosols. Soil Sci. Plant Nutr. 57:529-540.

64. Yasir, M., E.J. Chung, G.C., F. Bibi, C.O. Jeon, and Y.R. Chung. 2011. Chitinophaga eiseniae sp nov., isolated from vermicompost. Int. J. Syst. Evol. Microbiol. 61:2373-2378.

65. Yoon, S.J., Y.J. Choi, H.K. Min, K.K. Cho, J.W. Kim, S.C. Lee, and Y.H. Jung. 1996. Isolation and identification of phytase producing bacterium, Enterobacter sp. 4, and enzymatic properties of phytase enzyme. Enzyme Microb. Technol. 18:449-454. 